\title{
Oxygen Isotopes and Human Residential Mobility in Central Western Argentina
}

\author{
ADOLFO F. GIL, ${ }^{a *}$ GUSTAVO A. NEME, ${ }^{b}$ ANDREW UGAN ${ }^{c}$ AND ROBERT H. TYKOT ${ }^{d}$ \\ a CONICET, Museo de Historia Natural de San Rafael, Parque Mariano Moreno, San Rafael, Mendoza, \\ Argentina \\ b CONICET, Museo de Historia Natural de San Rafael, Parque Mariano Moreno, San Rafael, Mendoza, \\ Argentina \\ c Smithsonian Tropical Research Institute, Balboa, Ancón, Panamá \\ d Department of Anthropology, University of South Florida, Tampa, FL 33620, USA
}

\begin{abstract}
Stable oxygen isotopes $\left(\delta^{18} \mathrm{O}\right)$ from human bone apatite from central western Argentina (30-으는 latitude) were analysed to understand changes in human residential mobility during the Late Holocene. This region contains evidence for the use of domesticated plants over the last 2000 years (Zea mays, Cucurbita sp. and Phaseolus sp., among others), and previous models of prehistoric occupation have suggested a distinct change in mobility and population movement associated with their incorporation. The importance of these domesticates also seems to have varied geographically, being greater in the northern part of the region and declining as one moves south toward the limit with Patagonia. Expectations about patterns of residential mobility have varied accordingly.

To better evaluate these models, we analysed carbonate $\delta^{18} \mathrm{O}$ from the bone apatite of 71 individuals with radiocarbon dates spanning the last 6000 years. Given the existing evidence, we expected to see temporal and geographic differences in their oxygen isotope values associated with changes in residential mobility and the incorporation of different sources of drinking water available within the region. These expectations were not met. Significant variations were seen across all samples compared, both temporal and geographic, with no discernible differences among them. The data suggest that populations throughout the area were all highly mobile, and that this did not change with the incorporation of domesticates. Copyright @ 2011 John Wiley \& Sons, Ltd.
\end{abstract}

Key words: stable isotopes; $\delta^{18} \mathrm{O}$; Argentina; residential mobility; small-scale societies

\section{Introduction}

Residential mobility has been of substantial interest in archaeological studies of human adaptation (Bettinger, 1991; Kelly, 1995; Binford, 2001), particularly as it relates to prehistoric economies and how ancient people organised themselves relative to important resources. These issues have become increasingly important in the study of the late Holocene prehistory of western Argentina because of changing perspectives on exactly how indigenous people there made a living over the last 2000 years (Durán, 2000; Gil, 2006; Neme, 2007; Johnson et al., 2009).

At the time of European contact, the degree of residential mobility exhibited by indigenous populations in western Argentina varied with latitude and economy.

\footnotetext{
* Correspondence to: Departamento De Antropología, Museo De Historia Natural De San Rafael, Parque Mariano Moreno, San Rafael, Mendoza, Argentina. e-mail: adolfogil@arqueologiamendoza.org
}

Southern San Juan Province and Mendoza north of the Rio Atuel $\left(35^{\circ} \mathrm{S}\right)$ were occupied by the Huarpes (Figure 1), a group of relatively sedentary maize agriculturalists (for a discussion, see Lagiglia, 1977; 1978; Michieli, 1983; Prieto, 2002; but see García, 1992; 1998; Parissi 1992, 1995). Everything south to Neuquén Province $\left(35-40^{\circ} \mathrm{S}\right)$ was occupied by mobile hunters and gatherers such as the Puelches and Pehuenches (Michieli, 1979; Lagiglia, 1978; Durán, 2000). Archaeologists working in the region originally projected this dichotomous division back 2000 years, associating its origin with the arrival of maize agriculture in the region (Lagiglia, 1974, 1999).

Recent work has demonstrated that the picture is not so simple (Johnson et al., 2009; Gil et al., 2010). Although evidence of prehistoric domesticates is more common in southern San Juan (Lagiglia, 1978; Gambier, 2000; Johnson et al., 2009; Gil et al., 2010, 2011) and unknown from southernmost Mendoza and Neuquén, the current emphasis has been on the degree 


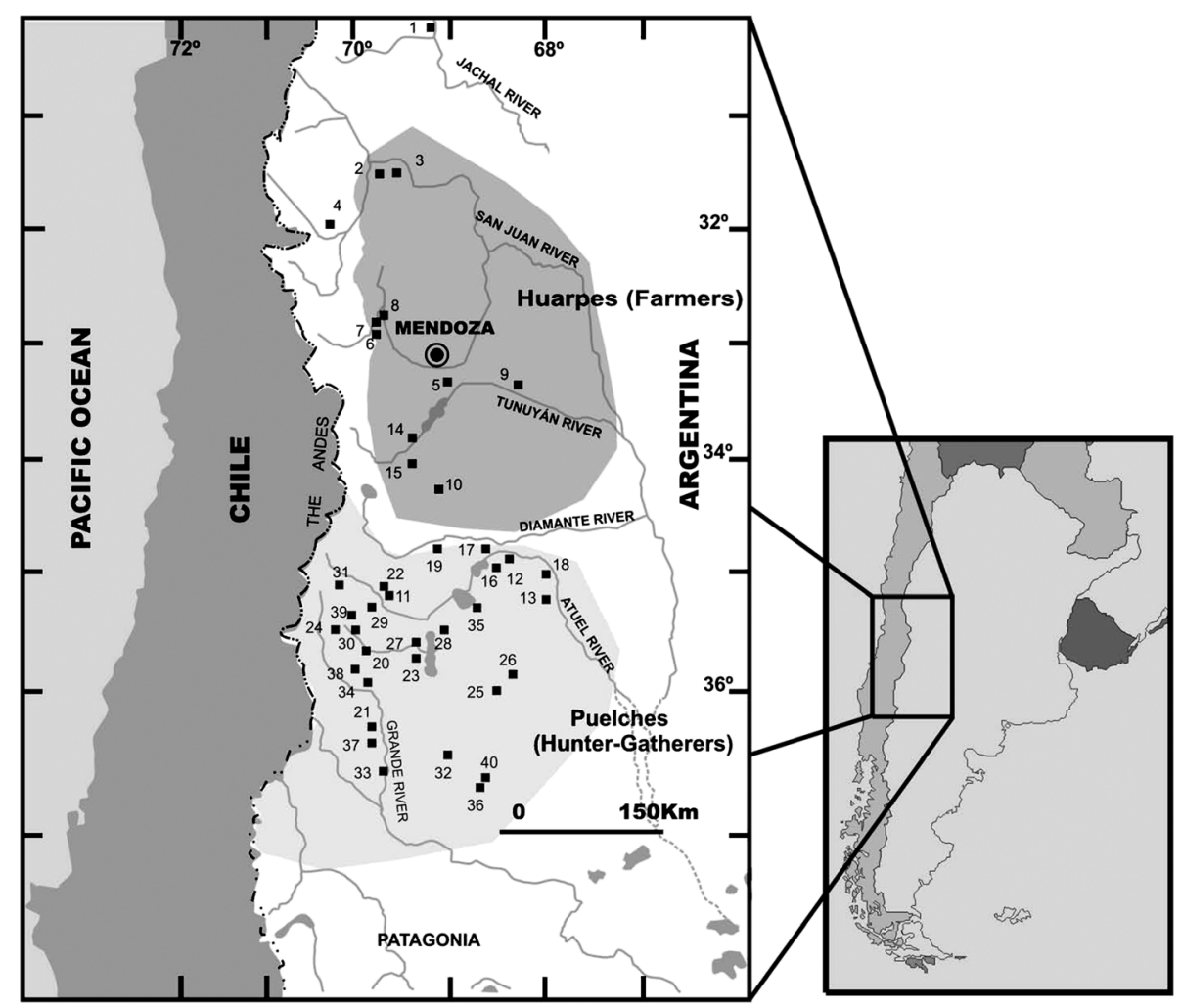

Figure 1. Simple ethnographic distribution in historic human population ca. 15th century and archaeological site mentioned in the text. References: 1-Angualasto y Punta del Barro; 2-Cerro calvario; 3-Calingasta; 4-Gruta 1 Los Morrillos; 5-Barrancas Yacimientos 1 y 2; 6-Potrero Las Colonias. 7-Uspallata; 8-Uspallata Túmulo I, II, III i 9-Alto Verde, 10-Capiz Alto; 11-Las Ramadas; 12—Rincón del Atuel; 13-La Olla; 14-Viluco; 15-San Carlos; 16-Cerro Negro and Gruta del Indio; 17-Cañada Seca; 18-Jaime Prats; 19-Médano Puesto Díaz; 20-Ea. Las Chacras; 21 -Buta Mallín, 22-Tierras Blancas; 23-Llancanelo, Pozos del Carapacho and Los Menucos; 24 -Cañada de Las Vizcachas and Arroyo Negro de Pincheira; 25-Cienaga de Borbarán; 26-RQ-1; 27-Cerro Trapal, 28-Norte de Llancanelo; 29-Ojo de Agua; 30-Cerro Mesa; 31-El Desecho and India Embarazada; 32-El Payén, 33-El Manzano; 34-Caverna de Las Brujas; 35-El Nihuil and Arbolito; 36-La Matancilla; 37-El Alambrado; 38-Mechenquil and Chenqueco; 39-El Chacay; 40-Agua del Toro.

of variability seen in prehistoric economies of northern and especially central Mendoza. The late Holocene archaeological record from northern Mendoza and southern San Juan, for example, contains direct and indirect evidence for maize-based agriculturalists (Gambier, 2000). This includes not only maize macrofossils but also more substantial architecture such as pit houses and burial mounds and larger quantities of decorated and simple ceramics from a range of vessel forms and sizes (Rusconi, 1962; Bárcena, 2001; Cortegoso, 2006). Nonetheless, isotope data from human remains in the north indicate that maize and other $\mathrm{C}_{4}$ plants played a small role in the diets of some and may have actually declined in importance after 500 years BP (Gil et al., 2009). Almost 20\% of the individuals for which we have data $(\mathrm{N}=27)$ have collagen $\delta^{13} \mathrm{C}$ values of $-17 \%$ or lower, and more than half have values indicative of mixed diets [approximately $-17 \%$ to $-14 \%$ $\delta^{13} C_{i} \delta^{13} \mathrm{C}$ values here and throughout the text are all relative to PeeDee Belemnite (PDB)]). These data suggest that wild resources remained an important component of prehistoric diets (Gil et al., 2006, 2009, 2010).

In central Mendoza, the archaeological record is largely consistent with mobile hunters and gatherers, exhibiting little or no evidence for long-term residences or substantial investment in residential structures, storage or ceramics. Yet there is also clear, albeit limited, evidence of domesticated maize macrofossils (Gil, 1997-1998, 2003, 2006; Llano, 2011). That image is again reinforced by the available isotopic evidence for human diet; numerous collagen $\delta^{13} \mathrm{C}$ values indicative of mixed $\mathrm{C}_{3}-\mathrm{C}_{4}$ diets $\left(\delta^{13} \mathrm{C}-18 \%\right.$ to $-14 \%$ ) occur over the same span of time and have been interpreted to indicate a partial reliance on maize agriculture (Gil, 2003). Variation in time, space and among individuals was likely the norm and maize never uniformly used as a staple in this region (Gil et al., 2009, 2010, 2011).

These observations, coupled with difficulty of dry farming in much of the region and the recognition that 
domesticates such as maize are not the only possible source of elevated $\delta^{13} \mathrm{C}$ signatures, have led to a great deal of debate about the nature of prehistoric economies. This includes questions of whether maize farming was ever an important mode of subsistence anywhere south of San Juan and, to the degree that it was, what it may have been like and how it may have been organised. Some, for example, have favoured the presence of fully sedentary farming groups even in the central area (Lagiglia, 1974, 1999), whereas others have proposed that hunter-gatherer populations interacted with more established farming groups both further north and in Central Chile (Gil, 1997-1998, 2000, 2003).

Associated with this changing view of intraregional economics is a related expectation regarding the degree of residential mobility seen in each area. If subsistence was based predominately if not exclusively on maize farming in the north, some mixture of agriculture and/ or hunting and gathering in the intermediate area and solely hunting and gathering in the south, these differences should be reflected in the degree of residential mobility-low in the north, intermediate in the centre, higher in the south and also higher before 2000 BP than after 2000 BP. Furthermore, these differences should be reflected in various aspects of the archaeological record.

Although some of these archaeological correlates have already been mentioned (architecture, ceramics, etc.), the size of the record, the number of sites on which it is based and their representativeness in terms of site type, location and excavation extent are all limited. To help address these shortcomings, we provide an additional line of evidence by testing this proposition using oxygen isotope data from the bone apatite of 71 individuals from western Argentina. In the sections that follow, we discuss how oxygen isotopes can be used to assess the geographic areas used by prehistoric people and how these data vary by period and subregion in western Argentina. We show that individuals throughout western Argentina seem to be relying on relatively ${ }^{18} \mathrm{O}$ enriched water sources such as rain, rain-recharged aquifers or reevaporated or mixed meltwater, with no detectable difference between samples from different regions (north, central and south) or elevations [highland piedmont (HP) versus lowland (LL)]. Finally, $\delta^{18} \mathrm{O}$ values from individuals dating before and after $2000 \mathrm{BP}$ also seem similar, providing no evidence for substantial changes in mobility despite the clear incorporation of domesticates. We conclude by discussing the implications of these findings for our understanding of late Holocene prehistory of western Argentina.

\section{Oxygen isotopes and mobility}

Oxygen isotopes provide a useful tool for assessing mobility in ancient populations (Sponheimer \& LeeThorp, 1999; Dupras \& Schwarcz, 2001; Knudson, 2009; Turner et al., 2009; Buzon et al., 2010; Sanhueza \& Falabella, 2010). Stable oxygen isotopes in the carbonate portion of hydroxyapatite $\left(\mathrm{Ca}_{10}\left(\mathrm{CO}_{3}\right)_{6}\right.$ $\left.\left(\mathrm{OH}_{2}\right)\right)$ of bone and tooth enamel reflect the isotopic composition of body water $\left(\delta^{18} \mathrm{O}\right)$ at $37^{\circ} \mathrm{C}$. Body water $\delta^{18} \mathrm{O}$ is influenced in turn by the oxygen isotopic composition of imbibed water and, to a lesser extent, oxygen in air and food sources, with predictable fractionation (Longinelli \& Nuti, 1973; Longinelli, 1984; Luz et al., 1984; Sponheimer \& Lee-Thorp, 1999, White et al., 2004; Turner et al., 2009). The isotopic composition of imbibed water is itself linked to latitude, altitude, aridity, seasonal temperature change and fluctuating rainfall in a given region through the variable loss of ${ }^{16} \mathrm{O}$ during evaporation and the progressive loss of ${ }^{18} \mathrm{O}$ during precipitation as air masses move inland and up in elevation (Dansgaard, 1964; Gat, 1996; White et al., 1998; White et al., 2004). These ecological processes make $\delta^{18} \mathrm{O}$ a useful measure of regional environmental variables, whereas the fact that these measures vary geographically allows us to assess an individual's movements (White et al., 2000, 2002; Dupras \& Schwarcz, 2001; White et al., 2004; Turner et al., 2009). Broadly speaking, human apatite $\delta^{18} \mathrm{O}$ values should reflect their sources of drinking water over the time period the apatite is laid down. Where water sources vary geographically and human mobility is limited, apatite $\delta^{18} \mathrm{O}$ values should also vary. Conversely, high mobility should lead to the use of multiple water resources and produce a weighted average of their $\delta^{18} \mathrm{O}$ signals.

Key to any argument about mobility is an assessment of the geographic variation in $\delta^{18} \mathrm{O}$ values of potential water sources (Knudson, 2009). West-central Argentina is a temperate region within the South American Arid Diagonal located between $30^{\circ}$ and $40^{\circ} \mathrm{S}$. It can be subdivided into three different environmental contexts: the western mountains (Andean cordillera) and piedmont, with winter precipitation between 300 and $1000 \mathrm{~mm} /$ year; the dry oriental plains, with summer dominant precipitation less than $250 \mathrm{~mm} / \mathrm{year}_{\text {; }}$ and the southeastern volcanic plateau or malpais of La Payunia, characterised by winter-dominant annual precipitation ranging from 200 to $400 \mathrm{~mm} /$ year (Capitanelli, 1972; Abraham \& Rodríguez, 2000; Morales et al., 2009). Although HP areas are common to the north, central and southern areas, the oriental plains dominate the northern and central LLs, and the volcanic regions of La Payunia 
occur almost exclusively in the south. These regions differ sharply from one another because of their relief, the dominant masses of maritime air that influence local weather patterns and the season of the year in which precipitations occurs (Bruniard, 1982; Morales et al., 2009). The piedmont and oriental plains are predominately influenced by the Atlantic anticyclone and the western cordillera and La Payunia by the Pacific Ocean anticyclone.

Although a limited amount of water isotope data exists for the area (Vogel et al., 1975; Osterra \& Dapeña, 2003; IAEA/WMO 2006; Hoke et al., 2009), some trends are apparent. First, much of the surface water in the highland (cordillera), piedmont and oriental plains consist of snow and glacial ice-melt from higher altitudes that flows down into the rivers (Figure 1). These waters originate mostly from the Pacific anticyclone (Norte, 2000), and river water in the highland has very low $\delta^{18} \mathrm{O}$ values typical of higher-altitude precipitation. These highland rivers also show some enrichment as altitude declines. Surface water $\delta^{18} \mathrm{O}$ values vary from $-18 \%$ (VSMOW) at $5500 \mathrm{~m}$ a.s.l. to approximately $-8 \%$ (VSMOW) at approximately $1000 \mathrm{~m}$ a.s.l., or an enrichment of roughly $0.48 \% \mathrm{o} /$ $100 \mathrm{~m}$ (Hoke et al., 2009).

The other major water sources are smaller wells or springs located throughout the eastern plains and malpais and badlands of La Payunia. Vogel et al. (1975) showed that springs in the eastern plains (LLs) are recharged by rivers. The $\delta^{18} \mathrm{O}$ values for such springs, which are common in LL settings, should be more like those of river waters from similar elevations (approximately -8\% VSMOW). Finally, there are also springs that are recharged by local rain rather than rivers (Vogel et al., 1975) and which have still higher $\delta^{18} \mathrm{O}$ values. Here we use a $\delta^{18} \mathrm{O}$ value of $-5.2 \%$ VSMOW (based on mean rainwater values reported by the IAEA/WMO, 2006). These springs are particularly common in La Payunia, where rivers are almost nonexistent and rain-recharged springs the norm.

All regions (north, central and south) have all three types of water sources (river, river-recharged spring and probably some rain-recharged spring), although the proportions vary. In general, $\delta^{18} \mathrm{O}$ values for individuals drinking waters from the oriental plains and $\mathrm{La}$ Payunia (hereafter LLs) should be higher than those who source their water from the mountains and foothills (HP), concordant with the few empiric studies available (Vogel et al., 1975; Osterra \& Dapeña, 2003; Hoke et al., 2009) (Figure 1). Similarly, individuals from the southern regions are likely to have more elevated $\delta^{18} \mathrm{O}$ values to the greater prevalance of rain-recharged springs in that area. Regardless of region, lower residential mobility should generally be reflected by increased variation in $\delta^{18} \mathrm{O}$ across individuals as they rely on a more restricted set of water sources.

\section{Materials and methods}

To test these propositions, 71 bone apatite samples, mostly cortical bone, were analysed for carbonate $\delta^{18} \mathrm{O}$. Bone apatite samples came mainly from long bones clearly identified as belonging to separate individuals. The number of individual is a significant sample of the human collections available in the region and representative of different environments and time periods. Table 1 presents the $\delta^{18} \mathrm{O}$ values for each sample as well as data on age, sex and chronology where available (mostly AMS, see details in Gil et al., 2010). Additional details on the samples themselves can be found in Gil et al. (2011).

The samples are grouped into six spatial units that reflect the prehistoric use of various water sources (Figure 1). From north to south, these units include southern San Juan and Mendoza north of the Rio Tunuyan (north, $\sim 30^{\circ}-33^{\circ} \mathrm{S}$ ), central Mendoza between Río Tunuyán and Rio Atuel (center, $\sim 34-35^{\circ} \mathrm{S}$ ) and southern Mendoza from the Río Atuel south to the Río Colorado (south, $\sim 36+{ }^{\circ} \mathrm{S}$ ). Each of these regions was further divided into HP and LLs depending on elevation.

Well-established procedures for extracting bone apatite were performed in the Laboratory for Archaeological Science at the University of South Florida (Tykot, 2004; Gil et al., 2009). For the extraction of carbonate from apatite, the sample was cleaned ultrasonically and crushed, sifted and sorted centrifugally. The collagen was removed by repeatedly soaking the bacterial and humic proteins with $2 \%$ sodium hypochlorite (bleach) solution. Bone was treated with $1 \mathrm{~mL}$ of $1 \mathrm{M}$ buffered acetic acid sodium acetate solution for $24 \mathrm{~h}$ to remove nonbiogenic carbonates. Experimental studies have shown this method to be successful in removing diagenetic contaminants (Koch et al., 1997; Tykot, unpublished data). The samples were analysed using a Finnigan MAT mass spectrometer coupled with a Kiel III device. The $\delta^{18} \mathrm{O}$ results are reported in relation to the Pee Dee Belemnite standard, using delta $(\delta)$ notation: $\delta^{18} \mathrm{O}$ (in \%o or per mil) $=$ $\left[\left\{\left(\right.\right.\right.$ sample $\left.{ }^{18} \mathrm{O} /{ }^{16} \mathrm{O}\right) /\left(\right.$ standard $\left.\left.\left.{ }^{18} \mathrm{O} /{ }^{16} \mathrm{O}\right)\right\}-1\right] \times$ 1000 . The stable isotope ratios produced have a precision better than $\pm 0.1 \%$ and have been calibrated against international standards analysed along with each set of samples. We did not attempt to assess recrystalisation or other diagenetic changes that may 
Table 1. Raw information of human bone apatite samples $\delta^{18} \mathrm{O}(\%$ VPDB)

\begin{tabular}{|c|c|c|c|c|c|c|c|c|c|}
\hline Region 1 & Region 2 & Sample & Archaeological site & Sex & Age & Code & ${ }^{14} \mathrm{C}$ & Code & $\delta^{18} \mathrm{O}_{\mathrm{AP}}$ \\
\hline HP & North & SJ1-ENT 7 & Morrillos Gruta 1 & & A & - & - & 7104 & -5.7 \\
\hline HP & North & SJ7-ENT2 & Morrillos Gruta 1 & & A & GAK-4704 & $4070 \pm 105$ & 7151 & -5.1 \\
\hline HP & North & SJ6-ENT8 & Morrillos Gruta 1 & $\mathrm{~F}$ & A & GAK-4809 & $1280 \pm 90$ & 7380 & -6.6 \\
\hline LL & North & SJ10-ENT1 & Angualasto & $\mathrm{F}$ & $A$ & - & - & 7159 & -3.7 \\
\hline LL & North & SJ4-ENT 2 & Angualasto & - & A & BETA-134392 & $650 \pm 40$ & 7142 & -3.3 \\
\hline LL & North & SJ2 & Calingasta & $\mathrm{M}$ & A & - & - & 7106 & -4.8 \\
\hline LL & North & SJ3-ENT3 & Punta del Barro & - & A & BETA-161362 & $590 \pm 40$ & 7110 & -4.9 \\
\hline LL & North & MMy-1263 & Barrancas yac. 2 & M & $\geq 45$ & AA-66560 & $2084 \pm 40$ & 8302 & -9.9 \\
\hline LL & North & MMy-1241 & Barrancas yac. 1 & $\mathrm{~F}$ & $17-20$ & - & - & 8301 & -6.6 \\
\hline HP & North & MMy-284 & Potreros Las Colonias & $\mathrm{F}$ & $30-45$ & AA-66564 & $568 \pm 38$ & 8309 & -7.6 \\
\hline $\mathrm{HP}$ & North & MMy-259 & Uspallata & $\mathrm{F}$ & A & AA-66558 & $1922 \pm 52$ & 8303 & -7.9 \\
\hline $\mathrm{HP}$ & North & MMy-229 & Uspallata Túmulo I & & $\geq 50$ & AA-66568 & $977 \pm 35$ & 8307 & -6.3 \\
\hline HP & North & MMy-239 & Uspallata Túmulo II & $\mathrm{F}$ & $\geq 50$ & AA-66561 & $1269 \pm 35$ & 8304 & -8.9 \\
\hline HP & North & MMy-243 & Uspallata Túmulo II & $\mathrm{F}$ & $38-53$ & AA-66565 & $1178 \pm 41$ & 8306 & -8.2 \\
\hline HP & North & MMy-245 & Uspallata Túmulo II & M & $35-45$ & - & - & 8305 & -8.3 \\
\hline HP & North & MMy-1097 & Uspallata Túmulo III & - & - & AA-66566 & $671 \pm 40$ & 8310 & -6.4 \\
\hline LL & North & MMy-1471 & Alto Verde & - & - & AA-66563 & $1736 \pm 49$ & 8308 & -7.3 \\
\hline LL & Center & ENT-2 & Capiz Alto & $\mathrm{F}$ & $40-45$ & - & - & 6227 & -6.9 \\
\hline LL & Center & MMy-1221 & San Carlos & $\mathrm{F}$ & $40-49$ & AA-66567 & $142 \pm 41$ & 8311 & -7.2 \\
\hline LL & Center & MMy-1223 & San Carlos & $\mathrm{F}$ & $19-23$ & AA-66562 & $177 \pm 34$ & 8300 & -10.1 \\
\hline LL & Center & MMy-1197 & Viluco & $\mathrm{F}$ & $40-45$ & AA-66559 & $208 \pm 38$ & 8299 & -8.7 \\
\hline LL & Center & GIRA-27 & Gruta del Indio & - & A & - & - & 6225 & -7.1 \\
\hline LL & Center & Gira-70 & Gruta del Indio & - & $A$ & AA-54670 & $2879 \pm 37$ & 6202 & -6.1 \\
\hline LL & Center & AF-830 & Gruta del Indio & - & - & AA-58280 & $3860 \pm 60$ & 8193 & -4.7 \\
\hline LL & Center & GIRA-831 & Gruta del Indio & - & - & AA-59588 & $3944 \pm 46$ & 7364 & -2.3 \\
\hline LL & Center & AF-828 & Gruta del Indio & $\mathrm{F}$ & $30-49$ & AA-58281 & $580 \pm 40$ & 8195 & -5.2 \\
\hline LL & Center & AF-500 & Rincón del Atuel & $M$ & $\geq 50$ & - & - & 6223 & -3.5 \\
\hline LL & Center & AF-503 & Rincón del Atuel & $\mathrm{F}$ & $35-49$ & - & - & 6204 & -3.7 \\
\hline LL & Center & AF-2000 & Cerro Negro & M & $27-34$ & AA-58279 & $580 \pm 35$ & 8191 & -4.8 \\
\hline LL & Center & AF-2019 & Cañada Seca & M & $\geq 50$ & - & - & 7350 & -3.7 \\
\hline LL & Center & AF-2018 & Cañada Seca & M & $30-35$ & - & - & 7355 & -2.8 \\
\hline LL & Center & AF-2020 & Cañada Seca & M & $50-56$ & LP-1184 & $1790 \pm 50$ & 7359 & -2.5 \\
\hline LL & Center & CS-10001 & Cañada Seca & M & $30-45$ & LP-1374 & $1420 \pm 60$ & 6200 & -5.4 \\
\hline LL & Center & JP-1155 & Jaime Prats & $\mathrm{F}$ & $20-26$ & - & - & 6220 & -6.7 \\
\hline LL & Center & JP/J4 & Jaime Prats & - & - & AA-59590 & $1887 \pm 42$ & 7348 & -8.6 \\
\hline LL & Center & JP-1352 & Jaime Prats & - & A & AA-59589 & $1880 \pm 49$ & 7339 & -5.8 \\
\hline LL & Center & $A F-1083$ & Arbolito & $\mathrm{F}$ & $35-50$ & AA-58284 & $97 \pm 36$ & 8199 & -7.7 \\
\hline LL & Center & MRM-21 & El Nihuil & - & - & AA-62938 & $274 \pm 45$ & 8379 & -9.6 \\
\hline LL & Center & AF-681 & Médano Puesto Díaz & $\mathrm{F}$ & $40-45$ & AA-59587 & $2865 \pm 52$ & 7361 & -4.3 \\
\hline HP & Center & AF-2072 & Las Ramadas & $\mathrm{F}$ & $15-18$ & & $965 \pm 35$ & 8197 & -4.6 \\
\hline HP & Center & MRM-20 & El Perdido & - & - & AA-62937 & $2936 \pm 60$ & 8378 & -2.9 \\
\hline LL & South & MRM-12 & Cienaga de Borbarán & M & $45-50$ & AA-62921 & $274 \pm 48$ & 8362 & -4.7 \\
\hline LL & South & MGA-1 & $R Q-1$ & - & - & - & - & 6215 & -3.0 \\
\hline HP & South & AF-2038 & El Desecho & $\mathrm{F}$ & $39-49$ & AA-54671 & $5502 \pm 60$ & 6218 & -7.3 \\
\hline $\mathrm{HP}$ & South & AF-2036 & India Embarazada & $\mathrm{F}$ & $16-20$ & AA-54672 & $2576 \pm 60$ & 6207 & -11.1 \\
\hline HP & South & AF-2025 & Tierras Blancas & $\mathrm{F}$ & $30-48$ & LP-890 & 200 & 7334 & -7.7 \\
\hline LL & South & Ent 3 & El Chacay & - & - & AA-59591 & $2321 \pm 66$ & 7343 & -4.7 \\
\hline $\mathrm{HP}$ & South & MRM-10 & El Chacay-Pto. Adobe & M & 20-34 & AA-62923 & $1472 \pm 34$ & 8364 & -8.3 \\
\hline HP & South & MRM-4 & Cañada de las Vizcachas & $\mathrm{F}$ & $25-35$ & AA-62922 & $573 \pm 33$ & 8363 & -6.1 \\
\hline $\mathrm{HP}$ & South & AF-508 & Cerro Mesa & M & $38-49$ & - & - & 6210 & -8.0 \\
\hline HP & South & AF-510 & Cerro Mesa & M & $\geq 50$ & - & - & 7330 & -5.0 \\
\hline LL & South & AF-2077 & Cerro Trapal & M & A & - & - & 8383 & -3.1 \\
\hline LL & South & MRM-13 & Las Chacras & $\mathrm{F}$ & $35-49$ & AA-62924 & $881 \pm 33$ & 8365 & -6.7 \\
\hline LL & South & MRM-7 & Llancanelo & $\mathrm{F}$ & $20-23$ & AA-62927 & $855 \pm 80$ & 8368 & -5.4 \\
\hline LL & South & MRM-5 & Llancanelo & $\mathrm{F}$ & $20-25$ & AA-62919 & $850 \pm 33$ & 8360 & -6.6 \\
\hline LL & South & MRM-25 & Llancanelo & - & A & AA-62926 & $900 \pm 36$ & 8367 & -5.5 \\
\hline LL & South & MRM-17 & Llancanelo & $\mathrm{F}$ & $20-25$ & AA-62934 & $1008 \pm 47$ & 8375 & -5.4 \\
\hline LL & South & MRM-1 & Llancanelo Norte & $M$ & $39-49$ & AA-62920 & $688 \pm 36$ & 8361 & -4.9 \\
\hline LL & South & MRM-14 & Pozos de Carapacho & - & A & AA-62928 & $797 \pm 30$ & 8369 & -8.8 \\
\hline LL & South & MRM-18 & Los Menucos & - & $A$ & AA-62935 & $863 \pm 47$ & 8376 & -7.2 \\
\hline $\mathrm{HP}$ & South & MRM-16 & Buta Mallín & - & - & AA-62933 & $2530 \pm 36$ & 8374 & -5.5 \\
\hline HP & South & & Caverna de las Brujas & - & A & AA-58283 & $3847 \pm 45$ & 8198 & -3.3 \\
\hline HP & South & AF-673 & El Manzano & M & $35-43$ & - & - & 7336 & -3.7 \\
\hline HP & South & MRM-24 & A Negro de Pincheira & - & - & AA-62941 & $358 \pm 45$ & 8382 & -7.6 \\
\hline
\end{tabular}


Table 1. (Continued)

\begin{tabular}{|c|c|c|c|c|c|c|c|c|c|}
\hline Region 1 & Region 2 & Sample & Archaeological site & Sex & Age & Code & ${ }^{14} \mathrm{C}$ & Code & $\delta^{18} \mathrm{O}_{\mathrm{AP}}$ \\
\hline HP & South & MRM-22 & El Chequenco & - & - & AA-62939 & $174 \pm 48$ & 8380 & -6.4 \\
\hline $\mathrm{HP}$ & South & MRM-8 & $\mathrm{A}^{\circ}$ - Mechenquil & - & - & AA-62931 & $148 \pm 31$ & 8372 & -7.3 \\
\hline HP & South & MRM-19 & El Alambrado & - & - & AA-62936 & $282 \pm 45$ & 8377 & -7.3 \\
\hline LL & South & AF-1082 & Agua del Toro & $\mathrm{F}$ & $35-49$ & LP-1368 & $210 \pm 60$ & 6213 & -3.9 \\
\hline LL & South & MRM-11 & El Payén & - & A & AA-62929 & $443 \pm 36$ & 8370 & -2.5 \\
\hline LL & South & AF-505 & La Matancilla & $\mathrm{M}$ & $45-50$ & LP-1379 & $470 \pm 50$ & 6198 & -3.9 \\
\hline
\end{tabular}

be (though are not necessarily) associated with the incorporation of exogenous oxygen sources (LeeThorp, 2002; Zazzo et al., 2004; Pellegrini et al., 2011). In addition to being young, the various remains studied here all had good collagen preservation and occurred in dry to very dry contexts, conditions that all reduce isotopic exchange. We are also interested in differences in $\delta^{18} \mathrm{O}$ among groups in a region where drinking water isotopes may vary by as much as $15 \%$ o to $20 \%$ rather than in paleothermometry or other applications where precise measurements of small-scale differences are critical.

\section{Results}

Bone apatite $\delta^{18} \mathrm{O}$ values average $-5.7 \%$ (PDB) $(n=71)$, with a standard deviation of 2.3 (maximum 0.8 , minimum -11.1). The most basic expectation was that variation in apatite $\delta^{18} \mathrm{O}$ values would decline from north to south as residential mobility climbed and individuals increasingly averaged over a range of possible water sources. This expectation was not met. Samples from each region exhibit similar trends in $\delta^{18} \mathrm{O}$, with no distinguishable differences in sample means or variances (Figure 2; one-way ANOVA,
$F=1.08, p=0.35$; Levene's test for equality of variances, $p=0.42$ ).

Similarly, our initial hypothesis was that there would be differences between HP and LL regions in the northern and central samples, but not in the south. This expectation also failed to hold. Here again, values for all regions $(\mathrm{N}, \mathrm{C}, \mathrm{S})$ and elevations (HP, LL) look essentially the same (Figure 3 ; one-way ANOVA, $F=2.35, p=0.05$; Levene's test for equality of variances, $p=0.28$ ). The only clear differences were for HP samples from the central versus northern region $(p=0.03$, Tukey's honestly significant difference).

This same pattern also holds when looking at temporal differences in $\delta^{18} \mathrm{O}$ values (Figure $4 ; \mathrm{N}$ and $\mathrm{C}$ before and after $2000 \mathrm{BP}$ ). The distribution of isotope values for samples before and after $2000 \mathrm{BP}$ remains broadly similar across regions (one-way ANOVA, $F=1.53, p=0.22$; Levene's test for equality of variances, $p=0.85$ ). This suggests that the consumption of drinking water was similar in the two periods. It also suggests that the lack of differences seen between regions in Figure 1 was not simply the result of mixing early and late samples.

Finally, we do not believe these patterns (or lack thereof) can be attributed to variation in paleoclimate. The currently available data provide little evidence

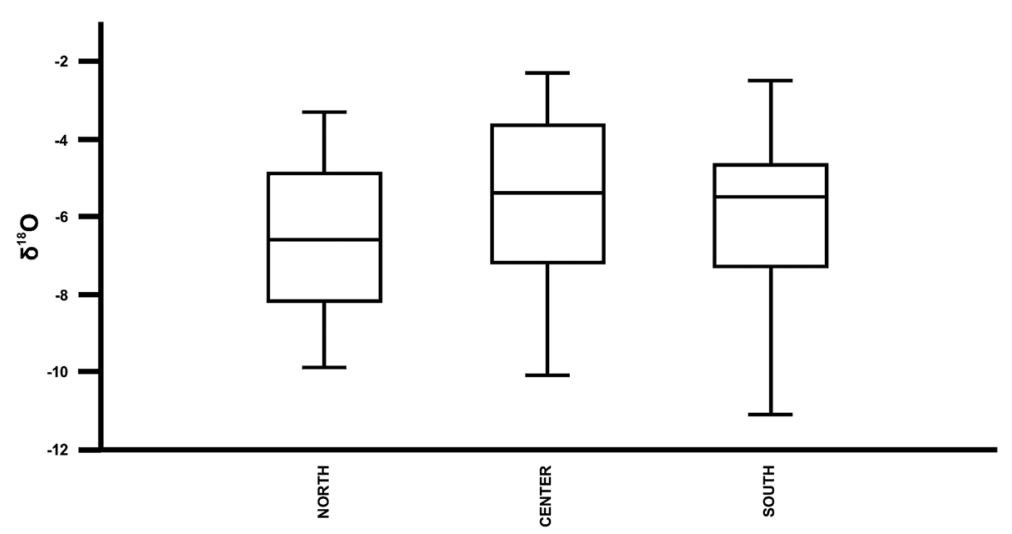

Figure 2. Latitudinal trends in $\delta^{18} \mathrm{O}$ in human bone apatite.

Copyright (C) 2011 John Wiley \& Sons, Ltd.

Int. J. Osteoarchaeol. 24: 31-41 (2014) 


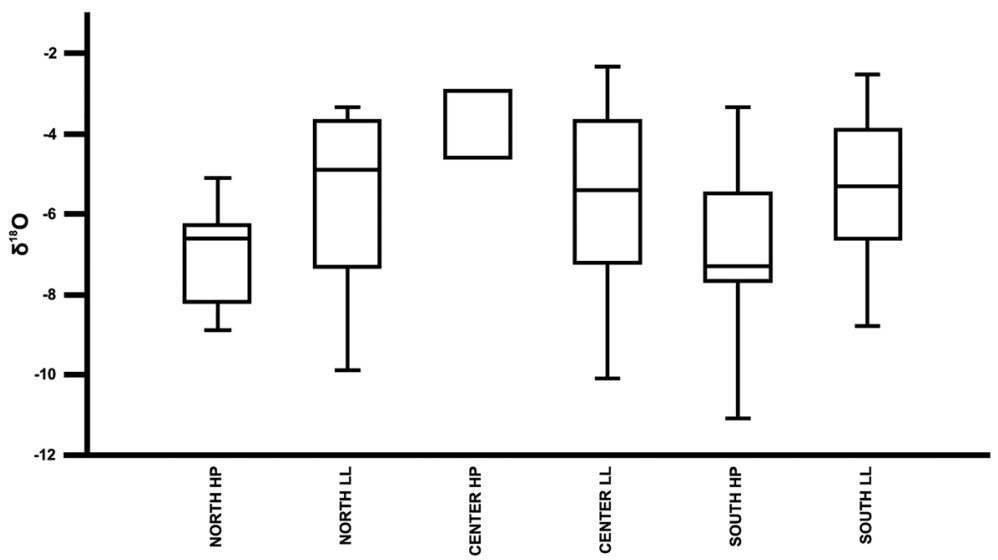

Figure 3. Latitudinal-longitudinal trends in $\delta^{18} \mathrm{O}$ in human bone apatite.

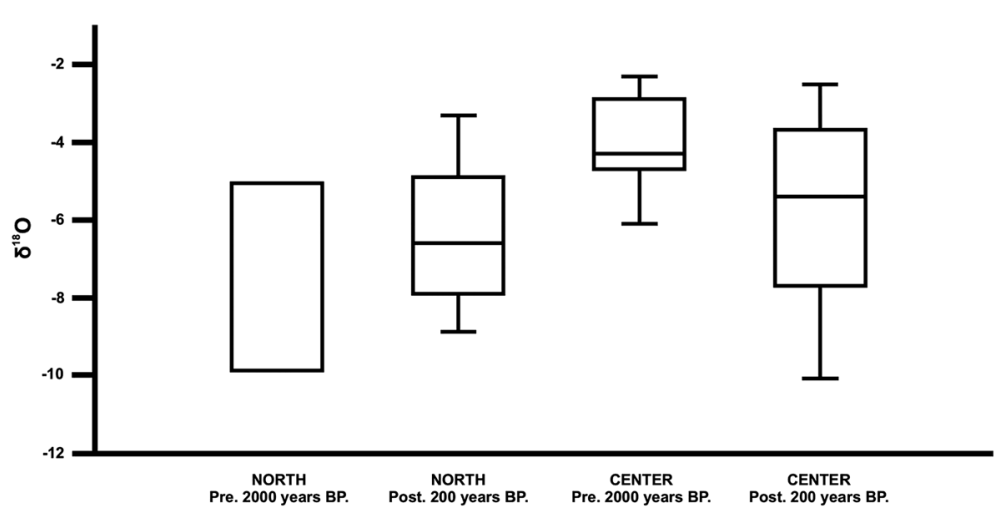

Figure 4. $\delta^{18} \mathrm{O}$ temporal difference before and after 2000 years BP in North and Center human bone apatite samples.

for significant variation in precipitation and temperature during the last 6000 years, and even less so for the last 3000 (when most of our samples occur; Zárate et al., 2010). Differences in precipitation may have been significant in terms of resource production and distribution but insufficiently large to alter the marked geographic differences in regional water $\delta^{18} \mathrm{O}$ values.

\section{Discussion}

Samples from all regions exhibit relatively positive $\delta^{18} \mathrm{O}$ values consistent with consuming waters from lower elevation locations. This is true regardless of whether the bodies sampled come from upper elevation HP locations or lower elevation desert plains. Moreover, even where there are hints of a difference such as highland and LL samples from the central region (Figure 3 ), the highland sample is actually the more positive. These data indicate that people obtained most of their water from lower elevation areas throughout central western Argentina.

Such a pattern may in part be a consequence of limited access to higher elevation areas. Although sites in the piedmont and highlands can be numerous, seasonal occupations are the norm (Durán, 2000; Durán et al., 2006; Gil, 2006; Neme, 2007). Moreover, occupation of the highlands can be particularly restricted, with snow and a short growing season limiting the use of the valleys and their highly depleted water sources to only four or five months of the year.

Limited access to highly depleted waters would also have the effect of narrowing the range of possible apatite $\delta^{18} \mathrm{O}$ values, making contrasts associated with differences in residential mobility harder to detect where they occur. This would become exacerbated by smaller sample sizes associated with subdividing regions by elevation (HP/LL) and an admittedly general picture of the distribution of actual water isotope values. While acknowledging these shortcomings, the data as they exist provide limited evidence for 
differences in residential mobility. As a consequence, we must consider the possibility that prehistoric people from southern San Juan south to the Río Grande were both substantially mobile and, in the northern areas, perhaps more reliant on wild resources than often believed.

This would imply a change in our view of regional prehistory, particularly in the northern periphery. The observed pattern strikes a sharp discord with the historic record, implying that the ethnohistoric context was in many ways distinctive and not readily extended to the last part of Late Holocene. This would not be unique but rather extend similar observations concerning a disconnect between the ethnohistoric and the archaeological records in the central region (e.g. Gil et al., 2009, 2011) further north. In this sense we need to consider a flexible farming-hunter/gatherer pattern with strong variation in time and space and where greater mobility was the norm.

For example, even where we have clear evidence of grinding equipment, ${ }^{13} \mathrm{C}$-enriched isotope signals and clear presence of cultivars such as maize, these could well be subsumed into a predominately mobile, subsistence strategy, perhaps analogous to ethnographically recorded patterns among Apache (Goodwin, 1935). Their maize is planted in better watered upland areas with little attention to either field preparation or tending. Moreover, some of the harvesting occurs while the maize is still green (Bellwood, 2004: 36; Hester, 1962; Snow, 1991), requiring regular replacement of seed stock. Estimates put contributions to the diet at less than $25 \%$ and highlight the substantial mobility of these people throughout the rest of the year, during which time they exploit numerous wild plant and animal resources.

A similar economic pattern would agree with the simpler nature of the Argentine archaeological record, especially in the central part of Mendoza, while still accounting for the macrobotanical evidence and allowing for some of the more positive $\delta^{13} \mathrm{C}$ values seen in the human remains (Gil et al., 2006, 2009, 2010, 2011). This includes not only the physical presence of maize and other cultivars but also their geographic distribution in sites along the flanks of the Andes and the Cerro Nevado upland (Gil, 1997-1998, 2006; Hernández et al., 2001; Llano, 2011) and the limited and equivocal evidence for field investments or irrigation systems (Mafferra, 2010: 2086). Finally, it would also allow for and agree with evidence for wide-ranging contact with groups both further north and particularly on the western side of the cordillera (Neme \& Gil, 2005).

If this characterisation is correct, it begs the question of how to account for the ethnohistoric record on which many archaeological interpretations have been based. However, a closer look at that record suggests room for interpretation. As mentioned earlier, the area from southern San Juan to central Mendoza was occupied by the Huarpes, who were characterised as sedentary farmers (Michieli, 1983: 23-24; Lagiglia, 1978; Prieto, 1997-1998: 59-60, 1999; Gambier, 2000: 670). Looking more carefully, however, one finds a continuum of behaviours ascribed to the inhabitants of the region, ranging from fully sedentary farming villages with irrigation, field crops and more complex social arrangements to less permanent farmers with an important wild resource component based on fishing, hunting and plant gathering (Michieli, 1983: 23-24; Prieto, 1998: 59-60; Gambier, 2000). Importantly, this sedentary pattern was influenced by the arrival of the Inca and later the Spanish (the former predating the latter by only a few decades). These affected the eastern and southern Huarpe populations to a greater degree, and they seem to have traded subsistence agriculture for a mixture of pastoralism, hunting and gathering at this time (Prieto, 1997-1998; Prieto Olavarría, 2008-2009: 156). This view suggests more complex spatial and temporal gradients in crop reliance even late, always with a strong hunting and gathering component in their diet, and this in turn must have had a measurable consequence on mobility. At some point, these patterns would be difficult to differentiate from the equally mobile, yet dedicated hunter-gatherers located further in southern Mendoza.

\section{Conclusions}

The province of Mendoza in western Argentina has long been viewed as a zone of agricultural transition. Domesticates first make an appearance in the area approximately 2000 years ago and have been considered to be an important component of prehistoric economies in the northern part of the region since that time. That importance has been thought to decline as one moves toward the frontier with Patagonia in the southern part of the province, where hunter-gatherers were always the norm. Accompanying this view has been a related expectation regarding general levels of residential mobility, with more stable residential patterns associated with a greater reliance on domesticates.

Given that this part of Argentina also exhibits fairly strong gradation in the isotopic values of drinking water sources, oxygen isotope values taken from human bone phosphate samples were expected to reflect differences in mobility across this same zone. They did not. Instead the data showed a very similar distribution of isotope values in individuals from the 
northern, central and southern part of the province, with few or no differences associated with being found in upland or LL locations. This lack of differentiation was seen as much in the variance as in mean oxygen isotope values.

This lack of a difference is surprising, giving the contrasting lifeways described for ethnohistoric populations from the northern (more sedentary, agriculturally focussed Huarpes) and central/southern part of the region (Pehuenches and Puelches hunter-gatherers). However, substantial archaeological work in central Mendoza over the last decade has pointed to a variable economic base, with a heavy reliance on wild resources and a more ephemeral use of domesticates, especially maize. The current work suggests that this same sort of circumstance may have also characterised much of northern Mendoza as well, leading us to rethink our image of prehistoric life in that area before the arrival of the Spanish in the 1500 s.

\section{Acknowledgements}

The authors thank Valeria Cortegoso, Victor Durán, Ramiro Barberena, Luciano Valenzuela and Clara Otaola for the discussions maintained and for providing important information. Museo 'Cornelio Moyano', Museo de Historia Natural de San Rafael, Museo and Instituto de Investigaciones Arqueológicas 'Professor Mariano Gambier' and Museo Regional de Malargue allowed the access to the human bone collections. Three anonymous reviewers made significant comments that the authors considered in this version. The analyses developed in the projects were funded by the following institutions: Consejo Nacional de Investigaciones Científicas y Técnicas, Agencia Nacional de Promoción de Ciencia y Tecnología (PICT 2006/00046 and IDAC ICES 2007/610), National Science Foundation (grant no. 0754353) and Museo de Historia Natural de San Rafael.

\section{Reference}

Abraham E, Rodríguez F. 2000. Argentina, Recursos y Problemas Ambientales de la Zona Árida. Programa de Cooperación para la Investigación. Universidades y Centros de Investigación de la Región Andina Argentina.

Bárcena R. 2001. Prehistoria del Centro Oeste Argentino. In Historia Argentina Prebispánica, E Berberián, A Nielsen (eds.) Ediciones Bruja: Córdoba: Argentina; 2: 561-634.

Bellwood A. 2004. First Farmers: The Origins of Agricultural Societies. Wiley-Blackwell: Oxford.
Bettinger R. 1991. Hunter-Gatherers: archaeological and evolutionary theory. Plenum Press: New York.

Binford L. 2001. Constructing Frames of Reference: An Analytical Method for Archaeological Theory Building Using Etbnograpbic and Environmental Data Sets. University of California Press: Berkeley, CA.

Bruniard E. 1982. La Diagonal Árida Argentina: un límite climático real. Revista Geografica 95: 5-20.

Buzon MR, Conlee CA, Bowen GJ. 2010. Refining Oxygen Isotope Analysis in the Nasca Region of Peru: An Investigation of Water Sources and Archaeological Samples. International Journal of Osteoarchaeology 21 : 446-455.

Capitanelli R. 1972. Geomorfología y clima de la Provincia de Mendoza. Boletín de la Sociedad Arentina de Botánica 13: $15-48$.

Cortegoso V. 2006. Comunidades agrícolas en el Valle de Potrerillos (NO de Mendoza) durante el Holoceno tardío: organización de la tecnología y vivienda. Intersecciones en Antropología 7: 77-94.

Dansgaard W. 1964. Stable isotopes in precipitation. Tellus 16: 436-468.

Dupras T, Schwarcz H. 2001. Stranger in a Strange land: stable isotope evidence for Human Migration in the Dakhleh Oasis, Egypt. Journal of Archaeological Science 28: 1199-1208.

Durán V. 2000. Poblaciones Indígenas de Malargüe. Serie Libro No1; CEIDER, Facultad de Filosofía y Letras. Universidad Nacional de Cuyo: Mendoza, Argentina.

Durán VA, Neme GA, Cortegoso V, Gil AF. 2006. Arqueología del área natural protegida Laguna del Diamante (Mendoza, Argentina). Anales de Arqueología y Etnología 61 : 81-134. Facultad de Filosofía y Letras, Universidad Nacional de Cuyo: Mendoza, Argentina.

Gambier M. 2000. Prebistoria de San Juan. Ansilta Editora: San Juan, Argentina.

García A. 1992. Hacia un ordenamiento preliminar de las ocupaciones prehistóricas agrícolas precerámicas y agroalfareras en el NO de Mendoza. Revista de Estudios Regionales 10: 7-34.

García EA. 1998. Economía y movilidad de las Comunidades huarpes prehispánicas. Revista de Estudios Regionales 20: 7-32. CEIDER, Mendoza, Argentina

Gat JR. 1996. Oxygen and hydrogen isotopes in the hydrologic cycle. Annual Review of Earth and Planetary Sciences 24: $225-262$.

Gil A. 1997-1998. Cultígenos prehispánicos en el sur de Mendoza. Discusión en torno al límite meridional de la agricultura andina. Relaciones de la Sociedad Argentina de Antropología 22-23: 295-318.

Gil A. 2000. Arqueología de la Payunia: sur de Mendoza. Tesis doctoral, 2 tomos. Facultad de Ciencias Naturales y Museo. Universidad Nacional de La Plata: La Plata, Argentina.

Gil A. 2003. Zea mays on the South American Periphery: Chronology and Dietary Importance. Current Antbropology 44: 295-300.

Gil A. 2006. Arqueología de la Payunia (Mendoza, Argentina). El poblamiento humano en los márgenes de la agricultura. BAR International Series 1477: Oxford. 
Gil AF, Neme GA, Tykot RH. 2010. Isótopos estables y consumo de maíz en el centro occidente Argentino: tendencias temporales y espaciales. Chungará 42: 497-513.

Gil A, Neme G, Tykot RH. 2011. Stable isotopes and human diet in central western Argentina. Journal of Archaeological Science 38: 1395-1404.

Gil AF, Neme GA, Tykot RH, Novellino P, Cortegoso V, Durán VA. 2009. Stable isotopes and maize consumption in central western Argentina. International Journal of Osteoarchaeology 19: 215-236

Gil AF, Tykot RH, Neme GA, Shelnut N. 2006. Maize on the frontier: isotopic and macrobotanical data from centralwestern Argentina. In Histories of Maize, J Staller, RH Tykot, B Benz (eds). Academic Press: London; 199-214.

Goodwin G. 1935. The social divisions and economic life of the western Apache. American Antbropologist 37: 55-64.

Hernández A, Lagiglia H, Gil A. 2001. El registro arqueobotánico en el sitio Agua de Los Caballos-1 (San Rafael, Mendoza). Anales de Arqueología y Etnología 54-55: 181-203.

Hester JJ. 1962. Early Navajo migrations and acculturation in the Soutbwest. Museum of New Mexico Press: Santa Fé.

Hoke G, Garzione1 CN, Araneo DC, Latorre L, Strecker M, Williams K. 2009. The stable isotope altimeter: Do Quaternary pedogenic carbonates predict modern elevations? Geology 37: 1015-1018.

IAEA/WMO. 2006. Global network of isotopes in precipitation. The GNIP database. Available at: http://isohis.iaea. org. (accessed 3 May 2011).

Johnson A, Gil AF, Neme GA, Freeman J. 2009. Maíces e intensificación: explorando el uso de los marcos de referencia. In Teoría, Métodos y Casos de Estudio en Arqueología Evolutiva, G López, M Cardillo (eds.) Colección de Complejidad Humana, Editorial SB: Buenos Aires, Argentina.

Kelly R. 1995. The Foraging Spectrum. Smitsonian Institution Press: Washington, DC.

Knudson K. 2009. Oxygen isotope analysis in a land of environmental extremes: the complexities of isotopic work in the Andes. International Journal of Osteoarchaeology 19: 171-191.

Koch, PL, Tuross, N, Fogel MLF. 1997. The effects of sample treatment and diagenesis on the isotopic integrity of carbonate in biogenic hydroxylapatite. Journal of Archaeological Science 24: 417-429.

Lagiglia H. 1974. Relaciones entre el Centro Oeste y el Noroeste argentino. Revista del Museo de Historia Natural de San Rafael 2: 103-118.

Lagiglia H. 1977. Dinámica cultural en el Centro Oeste y sus relaciones con áreas aledañas argentinas y chilenas. Actas del VII Congreso de Arqueología Chilena 2: 531-560 Chile.

Lagiglia H. 1978. La cultura de Viluco del Centro Oeste Argentino. Revista del Museo de Historia Natural 3: 227-265, San Rafael, Mendoza.

Lagiglia H. 1999. Nuevos fechados radiocarbónicos para los agricultores incipientes del Atuel. Actas del XII Congreso
Nacional de Arqueología Argentina, CD Marín (Ed.) 3: 239 250. La Plata. Buenos Aires.

Lee-Thorp J. 2002. Two decades of progress towards understanding fossilization processes and isotopic signals in calcified tissue minerals. Archaeometry 44: 435- 446.

Llano C. 2011. Aprovechamiento de los Recursos Vegetales entre las Sociedades Cazadoras-Recolectoras del Sur de Mendoza. Tesis Doctoral. Universidad Nacional del Comahue. Río Negro.

Longinelli A. 1984. Oxygen isotopes in mammal bone phosphate: a new tool for paleohydrological and paleoclimatological Research? Geochimica et Cosmochimica Acta 48: 385-390.

Longinelli A, Nuti S. 1973. Oxygen Isotope Measurements of Phosphate from Fish Teeth and Bones. Earth and Planetary Science Letters 20: 337-340.

Luz B, Kolodny Y, Horowitz M. 1984. Fractionation of oxygen isotopes between mammalian bonephosphate and environmental drinking water. Geocbimica et Cosmocbimica Acta 48: 1689-1693.

Mafferra L. 2010. La problemática en torno al registro arqueobotánico en el norte de Mendoza. Actas del XVII Congreso Nacional de Arqueología Argentina. Facultad de Filosofía y Letras. Universidad Nacional de Cuyo: Mendoza, Argentina; 2083-2088.

Michieli T. 1979. Los Puelches. Publicación 4. Instituto de Investigaciones Arqueológicas y Museo: San Juan, Argentina.

Michieli T. 1983. Los Huarpes protobistóricos. Instituto de Investigaciones y Museo. Facultad de Filosofía, Humanidades y Artes. Universidad Nacional de San Juan: San Juan, Argentina.

Morales M, Barberena R, Belardi JB, Borrero, LA, Cortegoso V, Durán VA, Guerci A, Goñi R, Gil AF, Neme GA, Yacobaccio H, Zárate MA. 2009. Reviewing Human-Environment Interactions in Arid Regions of Southern South America During the Past 3000 Years. Palaeogeograpby, Palaeoclimatology, Palaeoecology 281 : 283-295.

Neme GA. 2007. Cazadores-Recolectores de Altura en los Andes Meridionales. BAR International Series 1591: London, UK.

Neme GA, Gil AF. 2005. Aportes para la discusión del intercambio en el sur de Mendoza. Actas del XVI Congreso Nacional de Arqueología Chilena. Sociedad Chilena de Arqueología: Chile; 317-326.

Norte F. 2000. Mapa Climático de Mendoza. En: E Abraham, F Rodríguez Martínez (eds.) Argentina, Recursos y Problemas Ambientales de la Zona Árida, Mendoza, CRICYT: Argentina; 1 : 25-27.

Osterra H, Dapeña C. 2003. Environmental isotopes and geochemistry of Bañado Carilauquen, Mendoza, Argentina. In: IV South American Symposium on Isotope, Geology, Short Papers, CBPM, IRD: Brasili 461-464.

Parissi M. 1992. Algunos datos de las poblaciones prehispánicas del Norte y Centro Oeste de Mendoza y su relación con la dominación inca del área. Xama 4-5: 51-69. Mendoza.

Parissi, M. 1995. Aportes documentales y nuevas perspectivas sobre la organización sociopolítica prehispánica del 
Noerte y Centro Oeste de Mendoza. Cuadernos del Instituto de Antropología y Pensamiento Latinoamericano 16: 121-152.

Pellegrini M, Lee-Thorp JA, Donahue RE. 2011. Exploring the variation of the $\delta^{18} \mathrm{Op}$ and $\delta^{18} \mathrm{Oc}$ relationship in enamel increments. Palaeogeograpby, Palaeoclimatology, Palaeoecology (2011), doi:10.1016/j.palaeo.2011.02.023

Prieto M. 1997-1998. Formación y consolidación de una sociedad en un área marginal del Reino de Chile: la provincia de Cuyo en el Siglo XVII. Anales de Arqueología y Etnología 52-53: 1-366.

Prieto M. 1999. La frontera meridional mendocina durante los siglos XVI y XVII. Xama 2: 117-132. Mendoza.

Prieto Olavarría C. 2008-2009. La cerámica del cementerio indígena de Cápiz Alto (departamento de San Carlos, Mendoza). Una aproximación a las identidades culturales. Anales de Arqueología y Etnología 63-64: 151-175.

Rusconi C. 1962. Poblaciones Pre y Postbispánicas de Mendoza. Gobierno de Mendoza: Mendoza.

Sanhueza L, Falabella F. 2010. Analysis of Stable Isotopes: From the Archaic to the Horticultural Communities in Central Chile. Current Antbropology 51: 127-136

Snow D. 1991. Upland Prehistoric Maize Agriculture in the Eastern. Rio Grande and Its Peripheries. In Farmers, Hunters, and Colonists: Interaction Between the Soutbwest and the Southern Plains, K Spielmann (ed.) University of Arizona Press: Tucson; 71-88.

Sponheimer M, Lee-Thorp J. 1999. Oxygen isotopes in enamel carbonate and their ecological significance. Journal of Archaeological Science 26: 723-728.

Turner B, Kamenov GD, Kingston JD, Armelagos GJ. 2009. Insights into immigration and social class at Machu Picchu, Perú based on oxygen, strontium, and lead analysis. Journal of Archaeological Science 36: 317-332.

Tykot RH. 2004.Stable isotopes and diet: you are what you eat. In Pbysics Methods in Archaeometry, M Martini, M Milazzo, M
Piacentini (Eds.) Proceedings of the International School of Physics "Enrico Fermi" Course 154, Società Italiana di Fisica: Bologna, Italy; 433-444

Vogel J, Lerman J, Mook W. 1975. Natural Isotopes in Surface and Groundwater from Argentina. Hydrological Sciences-Bulletin-des Sciences Hidrologiques 20: 203-221.

White C, Longstaffe F, Law K. 2004. Exploring the effects of environment, physiology and diet on oxygen isotope ratios in ancient Nubian bones and teeth. Journal of Archaeological Science 31: 233-250.

White CD, Spence MW, Longstaffe FJ, Law KR. 2000. Testing the nature of Teotihuacan imperialism at Kaminaljuyu' using phosphate oxygen-isotope ratios. Journal of Antbropological Research 56: 535-558.

White CD, Spence MW, Longstaffe FJ, Stuart-Williams H, Law KR. 2002. Geographic identities of the sacrificial victims from the Feathered Serpent Pyramid, Teotihuacan: implications for the nature of state power. Latin American Antiquity 13: 217-236.

White CD, Spence MW, Stuart-Williams HL, Schwarcz HP. 1998. Oxygen isotopes and the identification of geographical origins: the Valley of Oaxaca versus the Valley of Mexico. Journal of Archaeological Science 25: 643-655.

Zarate, M, Gil AF, Neme GA. 2010. Integrando los registros: Generalizaciones, Alcances y limitaciones. In: M Zárate, A Gil, G Neme (Eds.) Condiciones Paleoambientales y Ocupaciones Humanas Durante La Transición PleistocenoHoloceno y Holoceno de Mendoza, Sociedad Argentina de Antropología; Buenos Aires: 309-330

Zazzo, A, Lécuyer C, Mariotti A. 2004. Experimentallycontrolled carbon and oxygen isotope exchange between bioapatites and water under inorganic and microbiallymediated conditions. Geochimica et Cosmochimica Acta 68: $1-12$. 